\title{
Crime and immigration: new evidence from England and Wales
}

\author{
Laura Jaitman ${ }^{1}$ and Stephen Machin ${ }^{2^{*}}$
}

\author{
* Correspondence: \\ s.machin@ucl.ac.uk \\ 2Department of Economics, \\ University College London and \\ Centre for Economic Performance, \\ London School of Economics, \\ London, UK \\ Full list of author information is \\ available at the end of the article
}

\begin{abstract}
We study a high profile public policy question on immigration, namely the link between crime and immigration, presenting new evidence from England and Wales in the 2000s. For studying immigration impacts, this period is of considerable interest as the composition of migration to the UK altered dramatically with the accession of Eastern European countries (the A8) to the European Union in 2004. As we show, this has important implications for ensuring a causal impact of immigration can be identified. When we are able to implement a credible research design with statistical power, we find no evidence of an average causal impact of immigration on crime, nor do we when we consider A8 and Non-A8 immigration separately. We also study London by itself as the immigration changes over time in the capital city were large. Again, we find no causal impact of immigration on crime from our spatial econometric analysis and also present evidence from unique data on arrests of natives and immigrants in London which shows no immigrant differences in the likelihood of being arrested.

JEL keywords: Crime; Immigration; Enclaves; A8

JEL classifications: F22, K42
\end{abstract}

\section{Introduction}

A large research literature has, over the years, studied the impact of immigration on economic outcomes. A prime focus in this work has been on the labour market impact of immigration, asking questions about the overall impact on wages and employment, but also on whether immigrants displace native workers or lower their wages through greater competition for jobs (see, inter alia, Altonji and Card 1991; Borjas 1999; Card 2005, 2009; or Dustmann et al. 2013). Other immigration impacts have also received attention, albeit to a lesser extent than the labour market work, including the impact of immigration on housing markets, usage of public services, welfare benefits and crime. In the past few years, these other impacts have received more attention and there are now growing numbers of contributions in these areas. ${ }^{1}$

In this paper, we present some new evidence on the impact of immigration on crime, using data from England and Wales. Ascertaining the magnitude and direction of an impact of immigration on crime is a high profile public policy question, but it is one on which we currently have only a limited number of robust findings. This is important since many media commentators and responses in public opinion polls postulate that immigration causes crime. Nevertheless, and standing contrary to this populist view, the (still

(C) 2013 Jaitman and Machin; licensee Springer. This is an Open Access article distributed under the terms of the Creative Commons Attribution License (http://creativecommons.org/licenses/by/2.0), which permits unrestricted use, distribution, and reproduction in any medium, provided the original work is properly cited. 
relatively small) literature that does exist finds it hard to detect an average impact of immigration on crime. For example, Bianchi et al. (2012) study crime and immigration across Italian areas, finding no significant empirical connection. Bell et al. (2013) conclude the same studying two large immigration waves in the UK.

A more subtle conclusion follows when a heterogeneous impact across different migrant groups is studied and, here, the extent of attachment to the labour market, and hence a source of legal income, seems critical. Bell et al. (2013) show that the very rapid influx of Eastern European migrants that entered the UK after the A8 accession countries joined the European Union in 2004 had no detrimental crime impact since the migrants actually had higher employment rates than natives. They do, however, find a positive, small, but statistically significant crime impact associated with the late 1990s wave of asylum seekers who were detached from the labour market. Spenkuch (2011) also emphasises immigrant heterogeneity in the US, breaking the immigrant stock into Mexicans and Non-Mexicans, and reports a significant positive crime effect for Mexican immigrants, while it is negative and insignificant for other immigrants.

In this paper, we present new causal evidence on the impact of immigration on crime, using a range of data sources from England and Wales. We consider the crimeimmigration relationship in the 2000s, a decade when the composition of migration altered dramatically with the accession of Eastern European countries (the A8) to the European Union in 2004. We estimate spatial panel data models of the crime-immigration relationship over the 2000s, and also present an analysis of differences in arrest rates of natives and migrants using unique data from the London Metropolitan Police Service.

As with some other work studying immigration impacts, we need to take care to identify a causal impact of immigration. To do so we adopt and further develop the enclave approach to immigrant settlement pioneered by Card (2001) where actual immigration flows are instrumented by a predicted settlement variable generated from overall immigration flows on the assumption that new migrants go to live in locations where earlier migrants from their origin country also settled. As already noted, because we are focussing on the 2000s in England and Wales, the significant compositional change of the structure of immigration flows has important implications for ensuring a causal impact of immigration can be identified. Our empirical analysis takes care to ensure we are able to implement this approach in a coherent manner for the setting we study.

When we are able to implement a credible research design with statistical power, we find no evidence of an average causal impact of immigration on criminal behaviour, nor do we when we consider A8 and Non-A8 immigration separately. We also consider London by itself as the immigration changes in the capital city in the 2000s were large. Again, we find no causal impact of immigration on crime from our spatial econometric analysis and also present evidence from unique data on arrests of natives and immigrants which shows no immigrant differences in the likelihood of being arrested.

The rest of the paper is structured as follows. In Section 2, we report descriptive information on immigration trends, placing a particular focus on the changing nature of migration flows. Section 3 discusses how to approach this in our spatial econometric analysis and reports evidence on when we are (and are not) able to utilise the enclave approach productively for our data. Section 4 reports evidence on the causal impact of immigration on crime. Section 5 then shows the analysis of arrest rates for natives and migrants. Section 6 concludes. 


\section{Trends in immigration to England and Wales}

\subsection{Data}

The main sources of immigration data for England and Wales are the decennial Population Census (1991, 2001 and 2011). For the inter-Census period in the 2000s we are able to use data from the Annual Population Survey (APS) which covers the financial years 2004/2005 to 2010/2011 (see Appendix B: Data Appendix and Jaitman and Machin 2013, for more details). Both data sources show that the nature of changing immigration was a significant phenomenon in England and Wales through the 2000s. They show the changes to be even more pronounced in London and, for that reason (and because we have data on arrests by nationality for London), we look at London separately in our analysis.

\subsection{Overall immigration trends}

According to the 2011 Census, one in eight people living in England and Wales - a total of 7.5 million out of 56 million - were born abroad. This shows a very big increase from 4.6 million (out of 52 million) in the previous Census in 2001 which in turn was up from 3.6 million (out of 50 million) in the 1991 Census. As Figure 1 shows, the share of immigrants therefore almost doubled from 1991 to 2011 in England and Wales, and grew at a faster rate in the 2000s as compared to the 1990s.

London has always been the main destination of foreigners, and changes in the capital city are even more marked. As the Figure shows, the share of immigrants grew from 21.7 percent in 1991 to 27.1 percent in 2001 and reached 36.7 percent in 2011. Hence, a significant part of the overall aggregate growth in the share of immigrants between 2001 and 2011 comes from London (for the rest of England and Wales it increased from 6.0 percent to 9.4 percent). In London the immigrant population was 1.5 million in 1991, increased to 1.9 million in 2001 and grew 58 percent in the following ten years to reach 3 million by $2011 .^{2}$

\subsection{The changing composition of immigration}

In the last decade, not only did the share of immigrants increase but also there were important changes in terms of the composition of their country of origin. In May 2004, eight Eastern European countries (the so called A8) joined the European Union ${ }^{3}$. The A8 countries are Estonia, Czech Republic, Hungary, Latvia, Lithuania, Poland, Slovakia

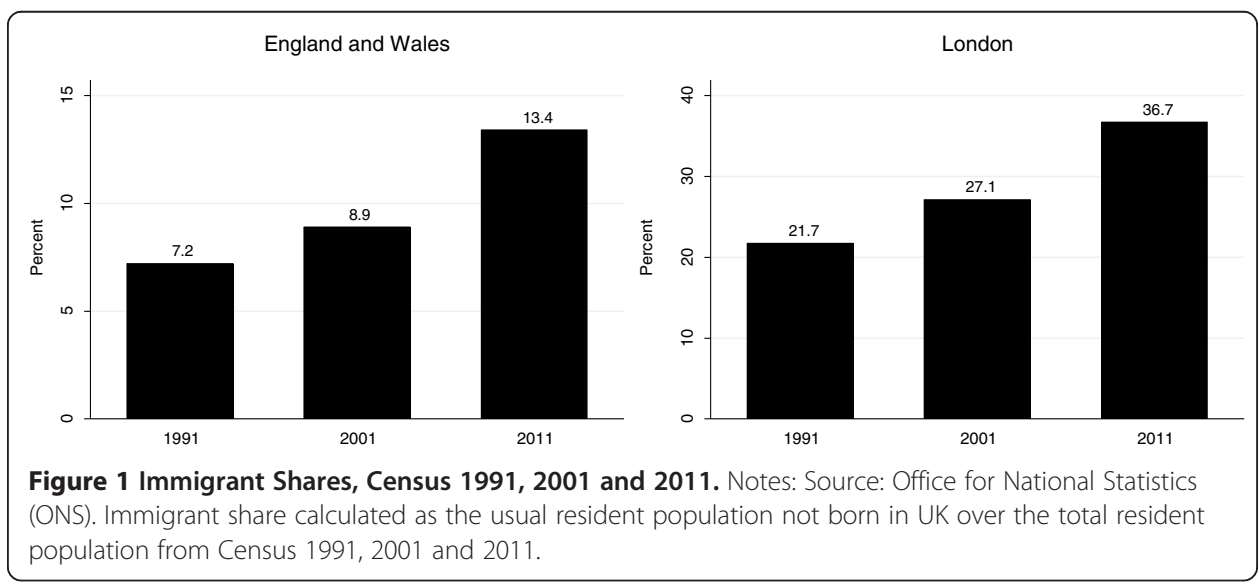


and Slovenia. In January 2007 two more countries (the A2, Bulgaria and Romania) gained access to the European Union. For the A8 citizens there was no restriction to work or live in the UK, as long as they registered with the Worker Registration Scheme (requirement that ended in 2011). The A2 citizens did face restrictions to access to labour markets (which will end in 2014).

This expansion of the European Union had a very big effect on the UK. Results from the 2011 Census suggest that about 1.1 million people were born in countries which joined the EU in 2004 or afterwards (almost 600,000 of those were born in Poland). This has important implications when studying the effect of immigration as the population of migrants from these origin countries were low in the previous Census.

For example, as shown in the first panel of Table 1, in the 2001 Census Poland did not feature in the top countries of UK residents born in a different country. Poland was actually placed in 17th, accounting for only 1.3 percent of the immigrant population. However, by 2011 Polish immigration is the fastest growing and it is ranked second, comprising 7.7 percent of the immigrant population. The second panel of Table 1 shows that in London Poland was ranked 18th in 2001, accounting for 1.1 percent of the immigrant population, and as for the country as a whole, it jumped to second place by 2011 accounting for 5.3 percent of the immigrant population.

Figure 2 reports the flows, rather than the stocks, to show the same point. Prior to 2004, the year of accession, flows from the A8 were negligible. In 2004, they rose to about 53,000 people and this steadily increased to 112,000 by 2007 , decreasing to 77,000 by 2011 . Thus the increase in the A8 flows from 2004 has significantly altered the composition of immigrant stocks in England and Wales. This has implications that should not be ignored or brushed over in empirical analysis of the impact of immigration over this time period, and this is what we turn to in the next Section of the paper.

\section{Empirical approach}

We plan to estimate spatial panel data models of crime and immigration flows, paying careful attention to the means of identifying a causal impact of immigration on crime. To do so we adopt the previous settlement/enclave approach of ensuring that the direction of causation flows from the immigrant variable to the outcome of interest, crime.

\subsection{Estimating equations}

For spatial data over time, our main equation of interest (expressed in differences for spatial unit $s$ between period $t$ and $t-1$, denoted by the difference operator $\Delta$ ) relates the crime rate to the immigrant/population ratio as:

$$
\Delta\left(\frac{\text { Crime }}{\text { Population }}\right)_{\text {st }}=\beta_{1} \Delta\left(\frac{\text { Immigrants }}{\text { Population }}\right)_{\text {st }}+\beta_{2} \Delta \mathrm{X}_{\text {st }}+\mathrm{T}_{\mathrm{t}}+\varepsilon_{\mathrm{st}}
$$

where $\mathrm{X}$ contains a set of time-varying controls, $\mathrm{T}$ is a common time effect and $\varepsilon$ is an error term.

The principal empirical challenge in estimating the key parameter of interest $\beta_{1}$ is, as already stated, the issue of possible reverse causation. We therefore use a 'previous settlement' type instrumental variable to predict the immigrant share. The logic of this arises from the notion that immigrants tend to settle in areas where there is already a high share of immigrants from their country of origin (what we call enclaves). The exogeneity of the 
Table 1 Immigrant composition by country of birth, Census and Annual Population Survey

\begin{tabular}{|c|c|c|c|c|c|c|c|c|c|c|c|}
\hline \multicolumn{3}{|c|}{ Census, 1991} & \multicolumn{3}{|c|}{ Census, 2001} & \multicolumn{3}{|c|}{ Annual Population Survey, 2005} & \multicolumn{3}{|c|}{ Census, } \\
\hline Rank & Country & $\%$ Share of immigrants & Rank & Country & $\%$ Share of immigrants & Rank & Country & $\%$ Share of immigrants & Rank & Country & $\%$ \\
\hline \multicolumn{12}{|c|}{ A. England and Wales } \\
\hline 1. & Ireland & 15.7 & 1. & Ireland & 10.2 & 1. & India & 9.8 & 1. & India & 9.3 \\
\hline 2. & India & 11.0 & 2. & India & 9.8 & 2. & Ireland & 7.2 & 2. & Poland & 7.7 \\
\hline 3. & Pakistan & 6.2 & 3. & Pakistan & 6.6 & 3. & Pakistan & 5.6 & 3. & Pakistan & 6.4 \\
\hline 4. & Germany & 5.6 & 4. & Germany & 5.3 & 4. & Bangladesh & 4.4 & 4. & Ireland & 5.4 \\
\hline 5. & Jamaica & 3.9 & 5. & Bangladesh & 3.3 & 5. & Germany & 4.4 & 5. & Germany & 3.6 \\
\hline$\cdots$ & & & $\cdots$ & & & $\cdots$ & & & & & \\
\hline 11. & Poland & 1.9 & 17. & Poland & 1.3 & 7. & Poland & 3.2 & & & \\
\hline \multicolumn{3}{|c|}{ Immigrants: 3.6 Million } & \multicolumn{3}{|c|}{ Immigrants: 4.6 Million } & \multicolumn{3}{|c|}{ Immigrants: 5.4 Million } & \multicolumn{3}{|c|}{ Immigrants: 7.5 Million } \\
\hline
\end{tabular}

\section{B. London}

$\begin{array}{cll}\text { 1. } & \text { Ireland } & 14.8 \\ \text { 2. } & \text { India } & 10.4 \\ \text { 3. } & \text { Jamaica } & 5.3 \\ \text { 4. } & \text { Kenya } & 3.9 \\ \text { 5. } & \text { Bangladesh } & 3.9 \\ \text {.. } & & \\ \text { 17. } & \text { Poland } & 1.5\end{array}$

$\begin{array}{lll}\text { 1. } & \text { India } & 8.9 \\ \text { 2. } & \text { Ireland } & 8.1 \\ \text { 3. } & \text { Bangladesh } & 4.4 \\ \text { 4. } & \text { Jamaica } & 4.1 \\ \text { 5. } & \text { Nigeria } & 3.6 \\ \text {.. } & & \\ \text { 18. } & \text { Poland } & 1.1\end{array}$

Immigrants: 7.5 Milion

Immigrants: 1.5 Million Immigrants: 1.9 Million

$\begin{array}{lll}\text { 1. } & \text { India } & 14.8 \\ \text { 2. } & \text { Bangladesh } & 10.4 \\ \text { 3. } & \text { Ireland } & 5.3 \\ \text { 4. } & \text { Jamaica } & 3.9 \\ \text { 5. } & \text { Nigeria } & 3.9 \\ & & \\ \text { 6. } & \text { Poland } & 3.5\end{array}$

Notes: Population by country of birth was obtained from the 1991, 2001, and
the list of countries available in the detailed country of birth tables (ONS). 


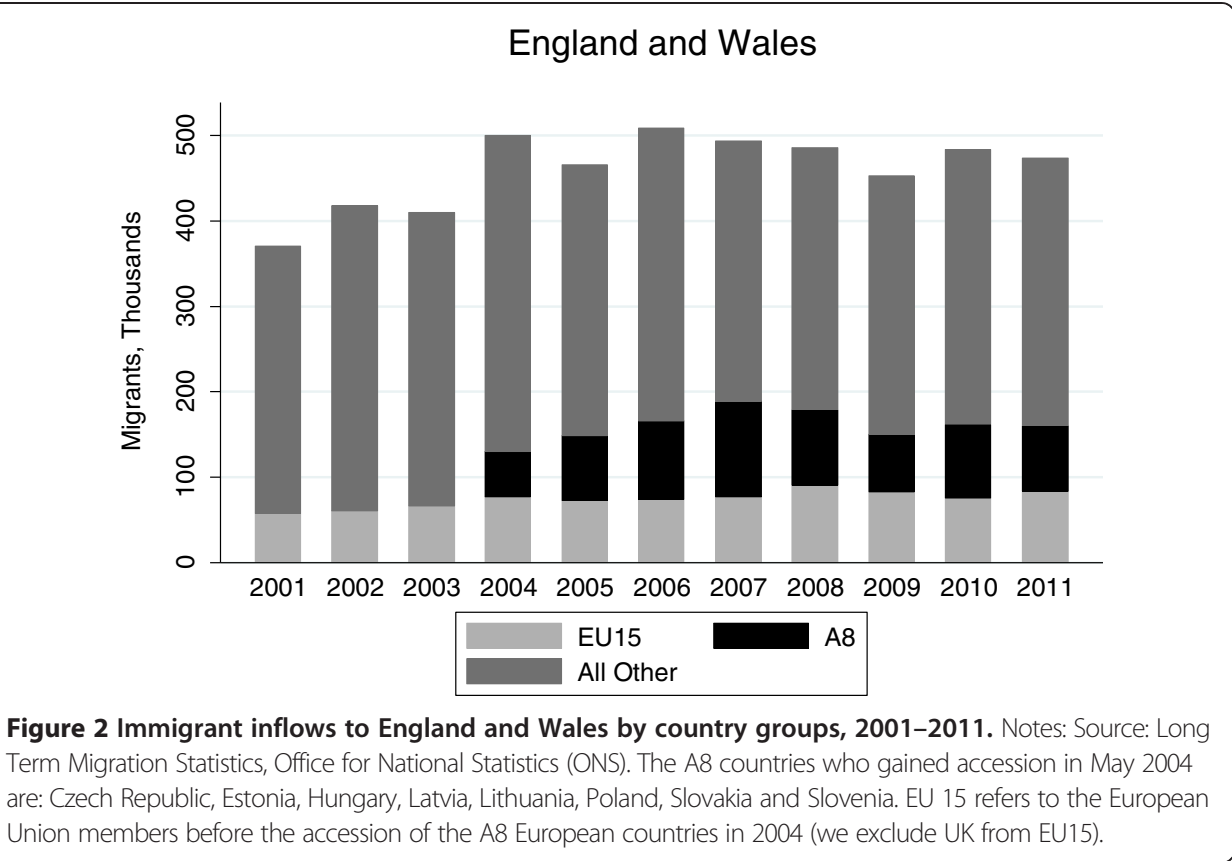

instrument relies on the assumption that there are no persistent shocks that could drive the location of immigrant settlements over time and that are correlated with the outcome variables of interest (in this case, crime trends).

More formally, the instrumental variable we use to predict the change in the share of immigrants for spatial unit $\mathrm{s}$ and initial time period $\mathrm{t}_{0}$, is the following:

$$
\Delta \mathrm{P}_{\mathrm{st}}=\left[\sum_{\mathrm{c}}\left(\mathrm{I}_{\mathrm{cst}_{0}} / \mathrm{I}_{\mathrm{ct}_{0}}\right) \Delta \mathrm{I}_{\mathrm{ct}}\right] / \text { Population }_{\mathrm{st}_{0}}
$$

where we use the initial distribution of immigrants from country c and allocate the flow of immigrants from that country between period 0 and 1 , according to that distribution in time 0 . We do this for 17 countries or country groups and sum the predicted change in immigrant share from each country. The selection of countries was based in their importance as immigrant sending countries or regions to the UK. ${ }^{4}$ We also include in the prediction an additional dummy variable for whether areas historically had a high immigration share, defined as 20 percent or over in the 1991 Census.

\subsection{The changing composition of immigration to England and Wales}

As the descriptive analysis of Section 2 showed, in the context we study the composition of migrant flows was dramatically altered by a big influx of migrants from different places than before. This has a potentially important impact on the usefulness or otherwise of the enclave type instrument described in equation (2). We therefore need to be careful in our empirical analysis to ensure that this changing composition does not invalidate the use of the enclave instrument.

Figure $3 \mathrm{~A}$ and $\mathrm{B}$ show enclave patterns for different sending regions and time periods across the local authorities in England and Wales. The horizontal axis shows the relative immigrant share ratio: the share of immigrants from country $c$ that lived in the spatial unit $s$ in the year $t_{0}$ divided by the share of total immigrants that lived in spatial unit $\mathrm{s}$ in the year $t_{0}$. 

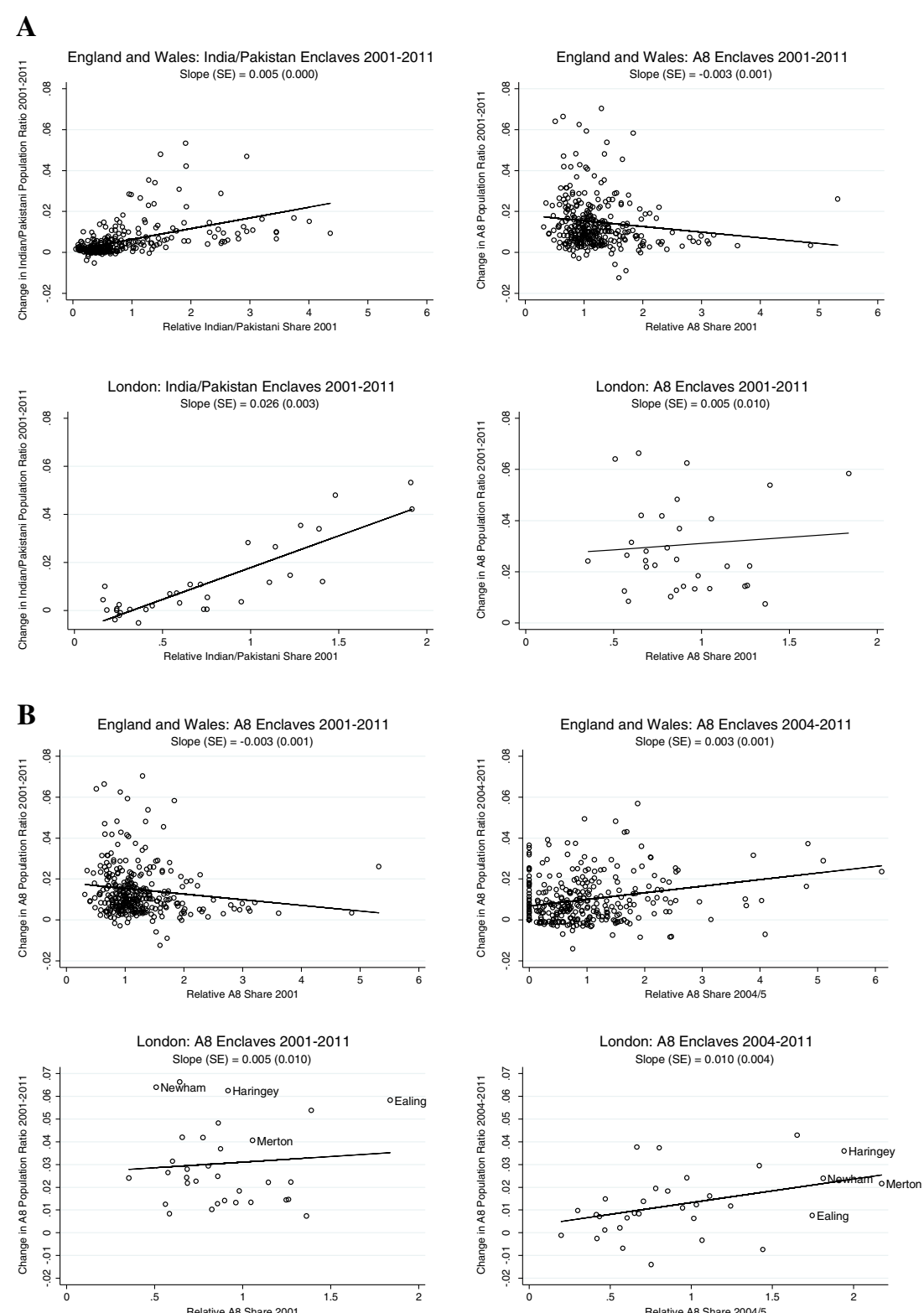

Figure 3 A: Enclave patterns. Census, 2001-2011. B: Enclave formation. Notes: The horizontal axis shows the relative immigrant share ratio: the share of immigrants from country $\mathrm{c}$ that lived in the spatial unit $\mathbf{s}$ in the year $t_{0}$ divided by the share of total immigrants that lived in spatial unit $s$ in the year $t_{0}$. The vertical axis shows the change in the ratio immigrantc/population of every spatial unit $s$ in the period $t_{0}$ to $t_{1}$. The slope and standard error of each regression is obtained from an OLS regression with population weights. Spatial units with less than 65,000 usual residents were excluded. The differences 2001-2011 are calculated with the Census data and the 2004-2011 with the APS, considering the relative shares as an average of the share in 2004/5 and 2005/6.

Values larger than one imply that the sending country $c$ is over-represented in the spatial unit $s$ relative to the average total immigrant population. A large value for the relative immigrant share from country $\mathrm{c}$ thus characterises an enclave. If we represent the immigrants coming from country $\mathrm{c}$ as $\mathrm{I}_{\mathrm{c}}$, the vertical axis shows the change in the ratio $\mathrm{I}_{\mathrm{c}} /$ population of every spatial unit $s$ in the period $t_{0}$ to $t_{1}$. A positive correlation between the relative immigrant share ratio and the change in the immigrant population from country c would 
suggest that net immigrant flows go to spatial units where there was already a significant settlement of immigrants from that country (established enclaves).

Figure 3A shows illustrative selected enclaves patterns for the period 2001-2011. The left column is for immigrants from India and Pakistan and the right one is for immigrants from A8 countries. We can see that the patterns are completely different. The case of India and Pakistan, which are traditional sending countries, shows a positive correlation, suggesting that there are established enclaves which are attractors for future migration inflows. On the contrary, the right column for A8 countries shows a negative or null correlation between the variables. This illustrates the fact that the A8 countries are new sending countries, and as such there were almost no established enclaves in 2001 (the only exception is the London borough of Ealing which had a large Polish concentration). From Figure $3 \mathrm{~A}$ we learn that using instrumental variables that rely on the previous settlement argument could be misleading in the case of new sending countries.

Figure $3 \mathrm{~B}$ focuses on the $\mathrm{A} 8$ countries. It shows the same enclave patterns plots for England and Wales (upper panel) and London (lower panel), and for different time periods: 2001-2011 (left column) and 2004-2011 (right column). ${ }^{5}$ The patterns prove to be sensitive to the period considered. When we analyse the inter-Census decade of 2001-2011, there were no established enclaves to predict future A8 flows. However, the Figure shows that some local authorities experienced a high increase in the A8 immigrant share (like Haringey or Newham) which can be indicative of a future enclave. In the 2004-2011 time period we can already see a positive correlation between the relative A8 immigrant share and the difference in A8 share of the local authority population. This suggests that in 2004/5-2005/6 period (in the 2 years following the accession to the European Union), the A8 immigrants settled and formed new enclaves (where the horizontal axis has values larger than one) and that the following net flows of A8 immigrants went to those same places, such as Haringey, Newham or also to the pre-existent enclave in Ealing.

Therefore, we can conclude from this analysis that the use of previous settlement arguments as a means of defining instrumental variables is likely to not be valid for the period 2001-2011 and also that it may work better when the enclaves from the new sending countries already formed. We assess this issue more rigorously, and across all migrant groups, in statistical models reported in the next Section of the paper.

\section{Spatial empirical models of crime and immigration}

\subsection{Data}

We report estimates of the spatial empirical models using local area data from England and Wales. Our crime data covers all local authorities in England and Wales. ${ }^{6}$ We use annual data on recorded notifiable offences by major offence type from the 43 Police Force Areas of England and Wales for the financial years 2002/2003-2011/2012, at local authority level. Prior to that a significant crime recording change occurred, which precludes analysis from before then. We have information on all crimes recorded by the police, and we also consider this broken down into violent and property crimes in some of our analysis. More information is given in the Appendix B: Data Appendix. The last column of Table 8 in the Appendix shows that the crime rate for all the country decreased from 103 per 1,000 population in 2002 to 65 per 1,000 population in 2011 . 
London also experienced the same trend, but in higher levels: the crime count decreased from 134 per 1,000 population to 87 per 1,000 population in the same period. The downward trend was common to both property and violent crimes.

The immigration data comes from the 2001 and 2011 Census and from the Annual Population Surveys (APS) that are available on an annual basis since 2004. We need to consider both of these to more formally probe further in statistical models the graphical analysis regarding the suitability of the enclave instrument $\mathrm{P}_{\mathrm{st}}$ as discussed in the previous Section of the paper. We have constructed various immigration stocks from the Census and APS for 347 local authorities ${ }^{7}$ and this is the spatial units we study. Within that there are 33 London boroughs and we also analyse them separately given the interesting 'experiment' offered by the very rapid immigration changes seen in the 2000s in the capital city.

Figure 5 in the Appendix shows the spatial distribution of crime rates and immigrant/ population ratios across local authorities in 2011. It is evident in this cross-sectional comparison that the darker areas (representing higher rates) do coincide to a degree across the two charts, indicating a positive correlation between immigration and crime. But this only implies that immigrants tend to settle in big cities like London, Manchester or Birmingham where crime rates are high, but also where they can presumably find better working opportunities. However, and as we have maintained throughout, it is important to look at changes across spatial units over time (so as to net out unobserved fixed differences) and to be careful to adopt a research design that try to ensure causality, which are the issues we next turn to in our statistical analysis.

Table 2 Changes in immigrant shares across local authorities, Census and Annual Population Survey

\begin{tabular}{|c|c|c|c|c|}
\hline & \multicolumn{4}{|c|}{ Dependent variable: change in immigrant share } \\
\hline & \multicolumn{2}{|c|}{ Census, 2001-2011 } & \multicolumn{2}{|c|}{$\begin{array}{c}\text { Annual Population Survey, } \\
2004 / 5-2010 / 11\end{array}$} \\
\hline & $(1)$ & $(2)$ & (3) & $(4)$ \\
\hline \multicolumn{5}{|l|}{ A. England and Wales } \\
\hline Predicted change in immigrant share & $0.353(0.059)$ & $0.359(0.067)$ & $0.560(0.098)$ & $0.574(0.095)$ \\
\hline High historical immigrant share & $-0.050(0.010)$ & $-0.044(0.011)$ & $-0.054(0.012)$ & $-0.054(0.013)$ \\
\hline Controls & Yes & Yes & Yes & Yes \\
\hline Police force area fixed effects & No & Yes & No & Yes \\
\hline F-test & 20.18 & 15.04 & 18.15 & 19.02 \\
\hline Sample size & 347 & 347 & 347 & 347 \\
\hline \multicolumn{5}{|l|}{ B. London } \\
\hline Predicted change in immigrant share & $0.150(0.105)$ & $0.153(0.107)$ & $0.698(0.130)$ & $0.674(0.130)$ \\
\hline High historical immigrant share & $-0.020(0.016)$ & $-0.021(0.016)$ & $-0.063(0.016)$ & $-0.062(0.016)$ \\
\hline Controls & Yes & Yes & Yes & Yes \\
\hline Police force area fixed effects & No & Yes & No & Yes \\
\hline F-test & 1.05 & 1.05 & 14.98 & 13.85 \\
\hline Sample size & 33 & 33 & 33 & 33 \\
\hline
\end{tabular}

Notes: Weighted by population. High Historical Immigrant Share is a dummy variable equal to one if the Immigrant Share in 1991 Census of the local authority is greater than 0.20. Controls are: population growth, the change in the unemployment rate, the change in the share of males aged 15-39 and a dummy variable for the 33 London boroughs. Robust standard errors in parentheses. 


\subsection{Statistical analysis - first stage}

The empirical models reported in Table 2 analyse the question of the suitability of the enclave instrument more formally. To do so we estimate the following first stage equation:

$$
\Delta\left(\frac{\text { Immigrants }}{\text { Population }}\right)_{\text {st }}=\delta_{1} \Delta \mathrm{P}_{\text {st }}+\delta_{2} \Delta \mathrm{X}_{\mathrm{st}}+\mathrm{T}_{\mathrm{t}}+\mathrm{v}_{\mathrm{st}}
$$

Estimates of (3) are given in Table 2, for various data configurations. ${ }^{8}$ The upper panel shows results for the 347 local authorities across the whole of England and Wales, and the lower panel for the 33 boroughs that are the 33 London local authorities. Of course, the results for London should be interpreted with some degree of caution as the sample size is only 33 spatial units. In all the estimations we adopt the standard practice of weighting the local authorities by their mean population of the periods under study (the results still hold if the data were not weighted, and if other periods' population weights were used).

Four specifications are shown in the Table. Specifications (1) and (2) show first differenced estimates based on Census data in 2001 and 2011, the difference between the two being that police force area fixed effects are not included in the former but are included in the latter (there are 43 police force areas of England and Wales and 2 police forces in London). Specifications (3) and (4) define the start year as 2004, the year of A8 accession, and show first differenced models from the 2004/5 and 2010/11 APS data without (3) and with (4) police force area fixed effects.

Table 3 Changes in immigrant shares across local authorities, census and annual population survey, A8 and Non-A8 instruments

\begin{tabular}{|c|c|c|c|c|}
\hline & \multicolumn{4}{|c|}{ Dependent variable: change in immigrant share } \\
\hline & \multicolumn{2}{|c|}{ Census, 2001-2011 } & \multicolumn{2}{|c|}{$\begin{array}{c}\text { Annual Population Survey, } \\
2004 / 5-2010 / 11\end{array}$} \\
\hline & (1) & (2) & (3) & (4) \\
\hline \multicolumn{5}{|l|}{ A. England and Wales } \\
\hline Predicted change in A8 immigrant share & $0.182(0.157)$ & $0.144(0.174)$ & $0.530(0.194)$ & $0.527(0.188)$ \\
\hline Predicted change in Non-A8 immigrant share & $0.438(0.099)$ & $0.469(0.120)$ & $0.583(0.143)$ & $0.622(0.165)$ \\
\hline High historical immigrant share & $-0.049(0.010)$ & $-0.043(0.011)$ & $-0.054(0.012)$ & $-0.055(0.014)$ \\
\hline Controls & Yes & Yes & Yes & Yes \\
\hline Police force area fixed effects & No & Yes & No & Yes \\
\hline F-test & 13.58 & 9.82 & 13.02 & 13.23 \\
\hline Sample size & 347 & 347 & 347 & 347 \\
\hline \multicolumn{5}{|l|}{ B. London } \\
\hline Predicted change in A8 immigrant share & $-0.011(0.272)$ & $-0.000(0.279)$ & $0.675(0.284)$ & $0.547(0.269)$ \\
\hline Predicted change in Non-A8 immigrant share & $0.229(0.193)$ & $0.227(0.198)$ & $0.730(0.269)$ & $0.840(0.270)$ \\
\hline High historical immigrant share & $-0.016(0.017)$ & $-0.017(0.018)$ & $-0.063(0.017)$ & $-0.064(0.017)$ \\
\hline Controls & Yes & Yes & Yes & Yes \\
\hline Police force area fixed effects & No & Yes & No & Yes \\
\hline F-test & 0.68 & 0.67 & 10.60 & 9.84 \\
\hline Sample Size & 33 & 33 & 33 & 33 \\
\hline
\end{tabular}

Notes: Weighted by population. The instrument for change in immigrant share is disaggregated into an A8 and a Non-A8 instruments. High Historical Immigrant Share is a dummy variable equal to one if the Immigrant Share in 1991 Census of the local authority is greater than 0.20 . Controls are: population growth, the change in the unemployment rate, the change in the share of males aged 15-39 and a dummy variable for the 33 London boroughs. Robust standard errors in parentheses. 
Considering first the Census results in specifications (1) and (2), it is evident that the enclave instrument predicts the actual change in immigration well for the whole country (as shown in the upper panel) but not at all well for London (as shown in the lower panel). For the latter the F-test for the instrument is very low as the estimated coefficient on $\Delta \mathrm{P}_{\text {st }}$ is not significantly different from zero. This highlights a first possible concern about the effects of changing composition for use of the enclave instrument.

If, however, the year of accession is used as the start year, as in the APS model in columns (3) and (4), things are a lot better. The magnitudes of the coefficients on the immigrant/population ratios are larger than in the Census and the F-tests are strongly significant for both England and Wales and London. ${ }^{9}$

The results given in Table 3 probe the composition question further by breaking up the instrument into A8 and Non-A8 immigrant/population ratios. This makes it very clear how the changing composition is affecting the suitability or otherwise of the enclave instrument. For the Census 2001 to 2011 differenced models for England and Wales, the Non-A8 immigrant variable predicts strongly, but the A8 immigrant variable is not significant. For London, the A8 variable has no explanatory power at all, and the Non-A8 variable is very weak. This casts strong doubt on using the enclave instrument in the 2000s using the 2001 Census settlement patterns to predict actual immigration flows.

A far better prediction arises if 2004 is used as the initial year. This is shown in specifications (3) and (4) of Table 3. For England and Wales as a whole and for London, both the enclave based predicted A8 and Non-A8 immigrant/population ratios are strongly related to the actual changes. Thus, we believe these specifications offer a sound first stage that we can use to go on to study the impact of changes in immigration on changes in crime in the 2000s. We will consider that next, before also showing some robustness checks that address some other possible concerns about our means of identification.

\subsection{Statistical analysis - second stage}

We now consider estimates of the change in crime model given in equation (1) above. Before doing so, it is worth considering the scatterplot of spatial changes

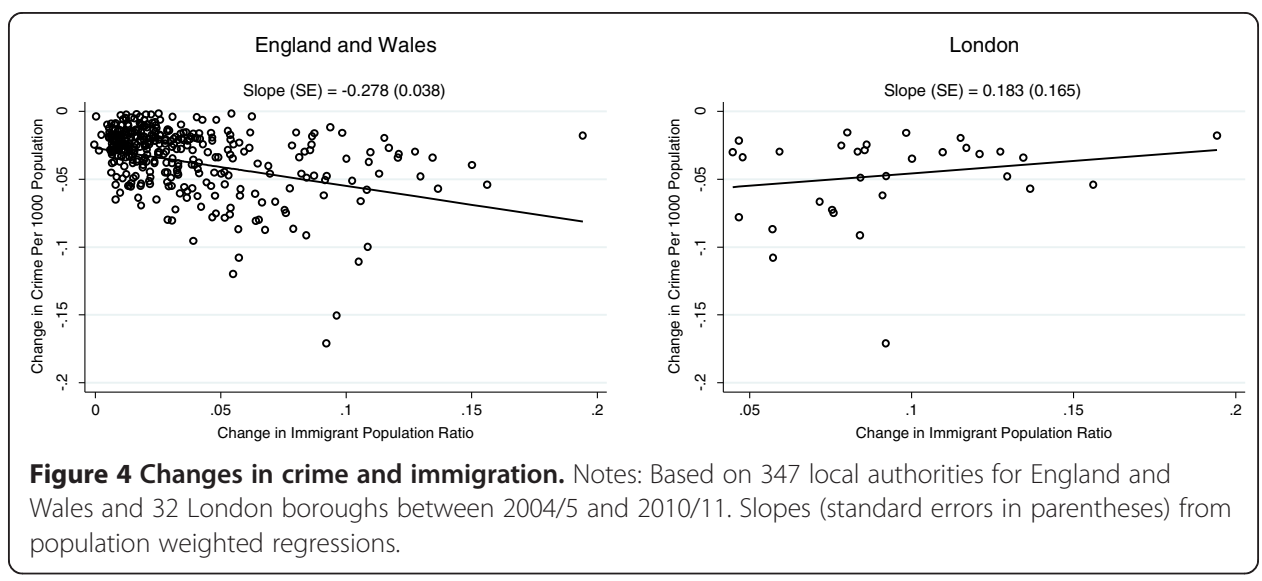


Table 4 Changes in crime and immigration

\begin{tabular}{|c|c|c|c|c|c|c|}
\hline & \multicolumn{6}{|c|}{ Dependent variable: change in crime rate } \\
\hline & \multicolumn{6}{|c|}{ Annual Population Survey, 2004/5-2010/11 } \\
\hline & OLS & IV Aggregate & IV A8 and Non-A8 & OLS & IV Aggregate & IV A8 and Non-A8 \\
\hline & $(1)$ & (2) & (3) & (4) & (5) & (6) \\
\hline \multicolumn{7}{|l|}{ A. England and Wales } \\
\hline Change in immigrant share & $-0.069(0.043)$ & $0.005(0.078)$ & $0.003(0.077)$ & $-0.051(0.035)$ & $0.007(0.078)$ & $0.000(0.078)$ \\
\hline Controls & Yes & Yes & Yes & Yes & Yes & Yes \\
\hline Police force area fixed effects & No & No & No & Yes & Yes & Yes \\
\hline Sample size & 347 & 347 & 347 & 347 & 347 & 347 \\
\hline \multicolumn{7}{|l|}{ B. London } \\
\hline Change in immigrant share & $0.042(0.077)$ & $0.100(0.090)$ & $0.099(0.091)$ & $0.092(0.059)$ & $0.120(0.088)$ & $0.108(0.093)$ \\
\hline Controls & Yes & Yes & Yes & Yes & Yes & Yes \\
\hline Police force area fixed effects & No & No & No & Yes & Yes & Yes \\
\hline Sample size & 33 & 33 & 33 & 33 & 33 & 33 \\
\hline
\end{tabular}

Notes: Weighted by population. Second stage estimates using first stages of Table 2 and Table 3 . Controls are: population growth, the change in the unemployment rate, the change in the share of males aged $15-39$ and a dummy variable for the 33 London boroughs. Robust standard errors in parentheses. 
in crime rates and changes in immigrant population shares which is given in Figure 4. For England and Wales, the purely descriptive Figure actually shows a negative regression slope. It is noteworthy that the places where the very big increases in immigrant shares have occurred do not seem to be characterised by increased crime. For London, there is an upward slope, but it is not strong and is nowhere near statistical significance. From these Figures, there seems to be no evidence of a positive crime-immigration link. However, these raw correlations need to be subjected to the more rigorous statistical analysis.

Table 4 therefore shows estimates of equation (1) across six specifications, again in the upper panel for England and Wales and the lower panel for London. Specifications (1)-(3) and (4)-(6) differ in that the former do not include the police force area fixed effects, whilst the latter do. Specifications (1) and (4) are ordinary least squares estimates. For both England and Wales, these show no significant correlation between changes in crime and changes in immigration.

The other four specifications are instrumental variable estimates, where (2) and (5) use the relevant first stages from Table 2 (what we call the aggregate instrument) and (3) and (6) use the relevant first stages from Table 3 (the separate A8 and Non-A8 instruments). In all four cases, there is no significant empirical connection between changes in the crime rate and changes in the immigrant/population ratio. This is the case for England and Wales, and for London. In the latter the estimated coefficients are a little larger in magnitude, but never approach statistical significance. Table 9 of the Appendix also confirms this to be the case when we consider violent and property crimes separately.

Thus, it seems we can find no evidence of a connection between crime and immigration from our descriptive analysis and from our causal research design. It seems that, despite the very rapid changes in immigration that occurred in England and Wales in the 2000s, they were not connected to increases in crime.

\subsection{Robustness checks}

We have subjected our core findings of Table 4 to a number of robustness checks. These are reported in Table 5. There are three main checks we undertook:

i) Specifications (1) and (2) show that the results are robust to considering specifications defined in changes in logs rather than changes in levels;

ii) Adding a (suitably instrumented) lagged dependent variable ${ }^{10}$, whilst showing evidence of spatial crime persistence, actually results in the coefficient on the change in the immigrant/population ratio turning negative (though remaining insignificantly different from zero);

iii) Because of the 2002 crime recording changes we also looked at the crime type that was least affected by these changes, namely burglary, to also implement a dynamic crime model. ${ }^{11}$ Again, there is evidence of spatial crime persistence, but the core finding of no connection between changes in crime and changes in immigration remains intact. 
Table 5 Robustness checks

Annual Population Survey, 2004/5-2010/11

Change in log crime rate

First stage Second stage

(2)

$0.008(0.060)$

High historical immigrant share

Change in immigrant share

Change in crime/burglary rate, 2002-2004

Controls

Police force area fixed effects

F-test

Sample size

\section{B. London}

Predicted change in immigrant share

High historical immigrant share

Change in immigrant share

$0.586(0.162)$

$-0.158(0.045)$

Yes

Yes

14.56

347

$0.761(0.460)$

$-0.159(0.050)$

Yes

Yes

347

Change in crime/burglary rate, 2002-2004

Controls

Police force area fixed effects

F-test

Sample size

-

$33-33$ in the unemployment rate, the change in the share of males aged 15-39 and a dummy variable for the 33 London boroughs. Robust standard errors in parentheses. In columns 3 and 5 there are two instrumented endogenous variables and the Angrist-Pischke multivariate F-Test of excluded instruments is reported. Burglary and Crime rates are burglary and crime counts divided by total population from the APS.
Change in crime rate,

Crime dynamics

First stage

(3)

Second stage

$0.555(0.099)$

$-0.055(0.0145)$

Change in burglary rate

Burglary dynamics

First stage Second stage

(5)

(6)

$0.558(0.097)$

$-0.055(0.014)$

$0.011(0.017)$

$0.475(0.124)$

$.292(0.042)$

Yes

Yes

347

$0.726(0.162)$

$-0.055(0.017)$

$0.671(0.136)$

$-0.048(0.020)$

$-0.080(0.056)$

$0.010(0.017)$

$0.182(0.021)$

$266(0.074)$

$\begin{array}{lcc}\text { Yes } & \text { Yes } & \text { Yes } \\ \text { Yes } & \text { Yes } & \text { Yes } \\ & 10.21 & \\ 33 & 33 & 33\end{array}$


Table 6 IV Estimates for A8 and Non-A8 immigrant, separate regressions

\begin{tabular}{|c|c|c|c|c|}
\hline & \multicolumn{4}{|c|}{$\begin{array}{l}\text { Dependent variable: change in crime rate } \\
\text { Annual Population Survey, 2004/5-2010/11 }\end{array}$} \\
\hline & \multicolumn{2}{|c|}{ A8 immigrant share } & \multicolumn{2}{|c|}{ Non-A8 immigrant share } \\
\hline & $\begin{array}{l}\text { First stage } \\
\text { (1) }\end{array}$ & $\begin{array}{l}\text { Second stage } \\
\text { (2) }\end{array}$ & $\begin{array}{l}\text { First stage } \\
\text { (3) }\end{array}$ & $\begin{array}{c}\text { Second stage } \\
\text { (4) }\end{array}$ \\
\hline \multicolumn{5}{|l|}{ A. England and Wales } \\
\hline Predicted change in A8 immigrant share & $0.289(0.075)$ & & & \\
\hline Predicted change in non-A8 immigrant share & & & $0.627(0.151)$ & \\
\hline High historical immigrant share & & & $-0.046(0.014)$ & \\
\hline Change in A8 immigrant share & & $-0.429(0.275)$ & & \\
\hline Change in non-A8 immigrant share & & & & $0.045(0.096)$ \\
\hline F-test & 14.91 & & 9.35 & \\
\hline Controls & Yes & Yes & Yes & Yes \\
\hline Police force area fixed effects & Yes & Yes & Yes & Yes \\
\hline Sample size & 347 & 347 & 347 & 347 \\
\hline \multicolumn{5}{|l|}{ B. London } \\
\hline Predicted change in A8 immigrant share & $0.213(0.091)$ & & & \\
\hline Predicted change in non-A8 immigrant share & & & $0.921(0.262)$ & \\
\hline High historical immigrant share & & & $-0.054(0.019)$ & \\
\hline Change in A8 immigrant share & & $0.130(0.469)$ & & \\
\hline Change in non-A8 immigrant share & & & & $0.117(0.130)$ \\
\hline F-test & 5.37 & & 6.24 & \\
\hline Controls & Yes & Yes & Yes & Yes \\
\hline Police force area fixed effects & Yes & Yes & Yes & Yes \\
\hline Sample size & 33 & 33 & 33 & 33 \\
\hline
\end{tabular}

Notes: Separate population weighted regressions for A8 and Non-A8 immigrants. High Historical Immigrant Share is a dummy variable equal to one if the Immigrant Share in 1991 Census of the local authority is greater than 0.20 . For A8 regressions this dummy is not included as there was no local authorities with high historical A8 immigrant shares. Controls are: population growth, the change in the unemployment rate, the change in the share of males aged 15-39 and a dummy variable for the 33 London boroughs. Robust standard errors in parentheses.

\subsection{Separate $\mathbf{A} 8$ and Non-A8 effects}

In the previous section, we have only distinguished between the A8 group of migrants and other migrants in the first stage regressions. However, it is possible that they are differentially correlated with changes in crime. Thus, in Table 6 we estimate separate regressions using A8 and Non-A8 immigrant/population ratios as explanatory variables. Again we are unable to detect any evidence of a causal crimeimmigration relationship, for either the A8 or Non-A8 groups.

\section{Arrests by immigrant status}

So far, we have analysed recorded crime data where the crime counts we have are not available broken down by immigrant status. To shed more light on the criminal behaviour of foreigners vis-à-vis natives, we have been able to obtain data on arrests by nationality from the Metropolitan Police Service (MPS), the police force that oversees 
Table 7 Differential arrest rates by nationality, London, 2009-2012

\begin{tabular}{cccccc}
\hline & \multicolumn{5}{c}{ Dependent variable: monthly arrest rate } \\
\cline { 2 - 6 } & \multicolumn{6}{c}{ Per $\mathbf{1}$,000 population (June $\mathbf{2 0 0 9}$ to June 2012), London Boroughs } \\
& $0.992(0.306)$ & $0.720(0.293)$ & $0.487(0.265)$ & $-0.048(0.212)$ & $-0.222(0.148)$ \\
Non-UK national & No & No & Yes & No & Yes \\
Borough fixed effects & No & No & No & Yes & Yes \\
Age fixed effects & Yes & No & No & No & No \\
Immigration offences & $2.822(0.196)$ & $2.820(0.196)$ & $3.369(1.030)$ & $3.287(0.212)$ & $3.943(0.278)$ \\
Constant & 512 & 512 & 512 & 512 & 512 \\
Sample size & & &
\end{tabular}

Notes: Non-UK national is a dummy variable equal to one when the nationality of the individual is not UK. The Age Fixed Effects are for eight age bands: 0 to 9,10 to 15,16 to 24,25 to 34,35 to 49,50 to 64,65 to 74 and older than 74 . Sample size is the number of cells (a cell is a combination of nationality status: either UK or Non-UK, age band and borough). Robust standard errors in parentheses. Data on arrests from the Metropolitan Police Service and population from the APS.

policing in 32 boroughs of London. ${ }^{12}$ We can thus present a brief empirical case study of London where we can study arrest rates of immigrants and natives.

We have monthly data covering the time period June 2009 to June 2012. For the 32 London boroughs we have counts of arrests broken down by nationality and age. We use APS data to construct arrest rates for UK nationals and Non-UK nationals by borough and age range ( 0 to 9,10 to 15,16 to 24,25 to 34,35 to 49,50 to 64,65 to 74 and over 75 years old). ${ }^{13}$

The overall monthly arrest rate for immigrants is significantly higher at 3.8 arrests per 1000 population than that for the 2.8 arrests per 1000 population for UK nationals to 3.5 arrests per 1000 population for Non-UK nationals. However, this includes arrests for immigration related offences, so it seems natural to exclude these. Nonetheless, the arrest rate is still significantly higher by 0.7 arrests per 1000 (from 2.8 arrests per 1000 population for UK nationals to 3.5 arrests per 1000 population for Non-UK nationals). The crimes for which people were arrested are similar in their profile for both groups, with assault and theft arrests ranking first and second for Non-UK and UK nationals.

It might be tempting to conclude from this that arrest rates are higher among NonUK nationals. However, there is another important feature to consider, in that the demographic structures of the two groups are different, particularly with respect to age. As crime is committed more by younger people this need to be taken into account. The age distribution of the population is very different for UK and Non-UK nationals, as most of the Non-UK nationals are in their mid 20s to mid 30s, the age in which arrests are higher.

In Table 7 we therefore pool the eight age groups by the two nationality groups across the 32 London boroughs and estimate an arrest rate equation, first only including a nationality status dummy, then borough fixed effects and then age range fixed effects. The first two specifications just reproduce the significant positive associations described before. Inclusion of the borough fixed effects reduces the gaps, but it remains positive and significant (at the 10 percent level). However, the age controls matter and completely wipe out the positive effects as seen in specifications (4) and (5). Table 10 of the Appendix shows the differential 
arrest rates for violent and property offences. The findings are the same as for total offences: a significant higher arrest rate for Non-UK nationals disappears once we control for age.

Thus, it is not that foreign nationals are arrested more, but the fact that they are concentrated in young ages and crime is higher amongst younger people. This is in line with the notion that immigrants' criminal behaviour is actually comparable to that of natives. The arrests case study of London thus corroborates the overall findings from our spatial econometric analysis and confirms we are unable to detect evidence of a positive crime-immigration link.

\section{Conclusions}

In this paper we offer some new evidence on whether one can detect an empirical connection between crime and immigration. To do so, we consider the very significant changes in immigration that occurred in England and Wales over the 2000s, where the share of immigrants in the total population rose by over 60 percent between the 2001 and 2011 Census years. With this change came a significant change in the composition of immigrants as the opening up to the A8 countries in 2004 resulted in a big immigration increase to England and Wales from countries where the prior number of immigrant settlements was relatively low.

In our modelling approach, we are careful to ensure that we are able to implement the enclave instrument traditionally used in the immigration research area in an effective way. For that purpose we have to define a start year after the opening up to A8 migration. When we do so, we find that the enclave instrument predicts well as the new migrants formed enclaves rapidly. Adopting this empirical approach to implement a causal research design, and contrary to the immigration causes crime' populist view expressed in some media and political debate, we find no evidence of an average causal impact of immigration on criminal behaviour. This is also the case when we study A8 and Non-A8 immigration separately. We also study London by itself as the immigration changes there were very dramatic. Again, we find no causal positive impact of immigration on crime from our spatial econometric analysis and also present evidence from unique data on arrests of natives and immigrants which as well shows no immigrant differences in the likelihood of being arrested.

\section{Endnotes}

${ }^{1}$ On housing markets and immigration see Saiz (2007) for US evidence and Sa (2011) for UK evidence. For evidence (respectively for the US and UK) on use of health services see Borjas and Hilton (1996) and Wadsworth (2013). Reviews of the research on welfare benefits are given in Barrett and McCarthy (2008) and on crime in Bell and Machin (2013).

${ }^{2}$ See Table 8 of the Appendix for more details on the sub-groups of immigrants.

${ }^{3}$ Apart from the A8 countries, Cyprus (excluding that part of the country under Turkish control) and Malta also joined the European Union. 
${ }^{4}$ The 17 groups are: Ireland, European Union countries as of 2001, A8 countries, Rest of Europe, India, Pakistan, Bangladesh, Sri Lanka, Rest of Asia, Kenya, South Africa, Ghana, Rest of Africa, Jamaica, North America, Rest of America and Oceania.

${ }^{5} 2004$ corresponds to the financial year 2004/5 and 2011 to the 2010/2011. The relative share in the horizontal axis is calculated considering the average distribution in 2004/5 and 2005/6 to gain precision, but the results also hold when considering only the 2004/5 cross-section.

${ }^{6}$ There are 348 local authorities in England and Wales.

${ }^{7}$ This excludes one very small local authority - the Isles of Scilly - for which sample sizes were just too small.

${ }^{8}$ The control variables we include in the differenced equations are: population growth, the change in the unemployment rate, the change in the share of males aged 15-39 and a dummy variable for the 33 London boroughs, the latter allowing for differential trends between London and the rest of the country. For more precise definitions, and sources, see the Appendix B: Data Appendix.

${ }^{9}$ We also estimated specifications (3) and (4) using a nationality based immigration variable (instead of country of birth). This is available only for the APS and the instrument performs reasonably well, producing qualitatively similar though numerically a little smaller results, and the estimates are on the margins of significance in the London specifications (see Table 2 of Jaitman and Machin 2013, for these estimates).

${ }^{10} \mathrm{We}$ are severely constrained in this exercise by the crime recording changes that came into place first in the 2002 recording year with the adoption of the National Crime Recording Standard by the 43 police forces in England and Wales. This means that there are no available comparable crime records before then (see Jaitman and Machin (2013) for more details on the recording changes). So the lagged dependent variable is the change in crime between 2002 and 2004. In a first differenced specification the coefficient on the lag is biased and so we need to instrument it which we do using the 2002 crime rate. This is strongly correlated - the F-test of this first stage regression was 13.7 for England and Wales and 132.68 for London. Regarding the first stage for the change in the immigrant share, we find no evidence that the settlement patterns of immigrants are correlated with the 2002 area crime rates - the relevant coefficient estimates (standard errors) were 0.036 (0.064) for England and Wales and -0.155 (0.155) for London.

${ }^{11}$ See Simmons et al. (2003) for evidence that burglary was less affected by the crime recording changes as compared to other crimes (notably violent crimes).

${ }^{12}$ There is a separate police force for the 33rd borough, the City of London.

${ }^{13}$ The reason for using APS rather than Census data is that the way nationality is defined by the police is much closer to the APS definition. See Appendix B: Data Appendix for more information.

\section{Appendix A: Additional Figures and Tables}

This Appendix includes a number of additional Figures (Figure 5) and Tables (Tables 8, 9 and 10) referred to in the text of the main body of the paper. 


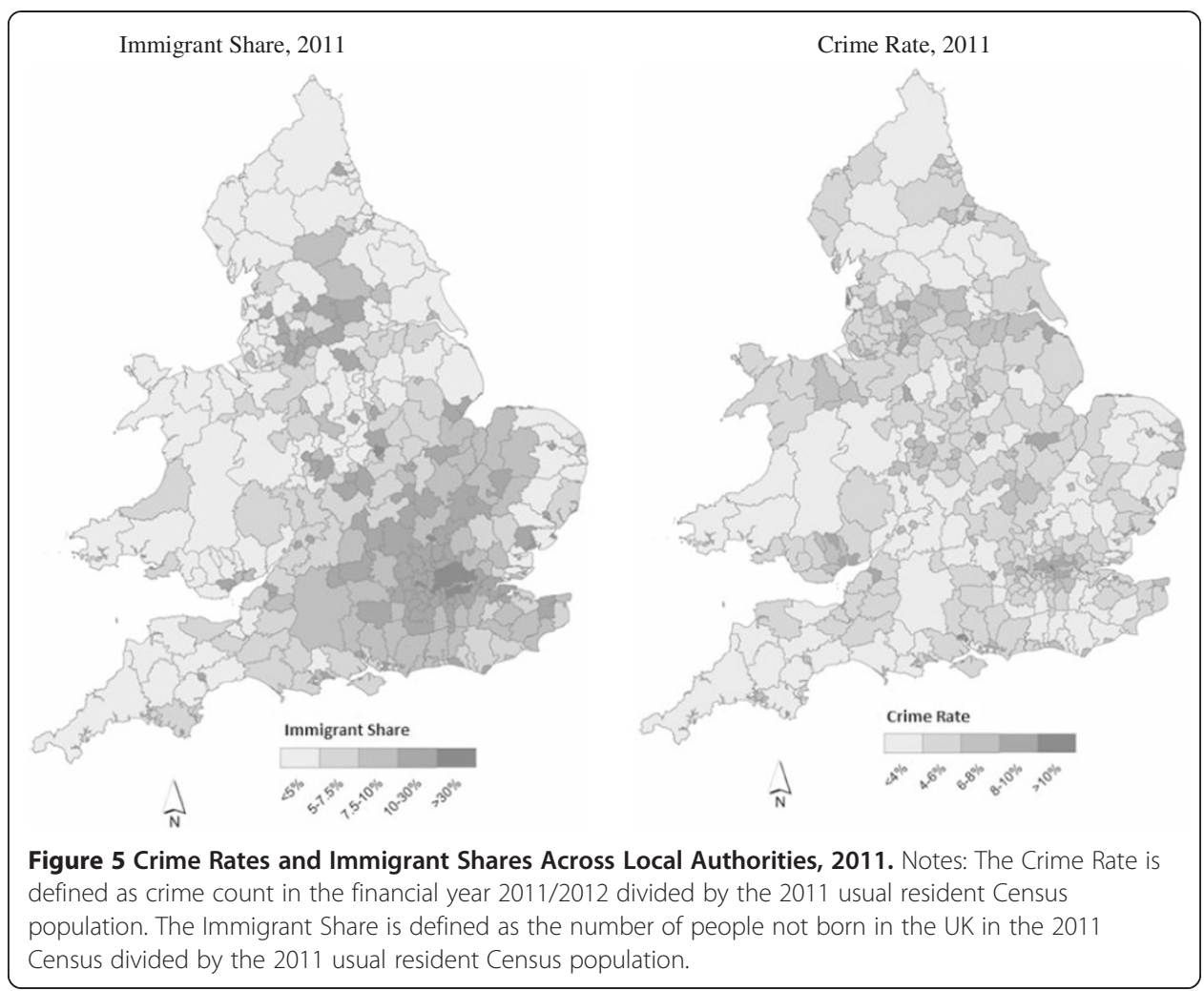

Table 8 Summary Statistics from Census 2001 and 2011, and APS 2004/5

\begin{tabular}{llll}
\hline & Census, 2001 & APS, 2004/5 & Census, 2011 \\
\hline $\begin{array}{llll}\text { A. England and Wales } \\
\text { Immigrant share }\end{array}$ & 0.089 & 0.096 & 0.134 \\
Of which: & & & \\
Ireland & 0.106 & 0.085 & 0.053 \\
EU 15 & 0.126 & 0.126 & 0.107 \\
A8 & 0.020 & 0.033 & 0.116 \\
Rest Europe & 0.041 & 0.068 & 0.054 \\
Asia & 0.390 & 0.380 & 0.383 \\
Africa & 0.170 & 0.207 & 0.178 \\
America & 0.118 & 0.075 & 0.089 \\
Oceania & 0.029 & 0.027 & 0.020 \\
& & & 0.062 \\
Unemployment rate & 0.052 & 0.047 & 0.167 \\
Young males rate & 0.170 & 0.171 & 234643 \\
Population & 215540 & 218004 & 0.065 \\
Total crime rate & 0.103 & 0.097 &
\end{tabular}


Table 8 Summary Statistics from Census 2001 and 2011, and APS 2004/5 (Continued)

\begin{tabular}{|c|c|c|c|}
\hline & Census, 2001 & APS, $2004 / 5$ & Census, 2011 \\
\hline \multicolumn{4}{|l|}{ B. London } \\
\hline Immigrant share & 0.271 & 0.300 & 0.367 \\
\hline \multicolumn{4}{|l|}{ Of which: } \\
\hline Ireland & 0.082 & 0.061 & 0.043 \\
\hline EU 15 & 0.107 & 0.117 & 0.108 \\
\hline A8 & 0.020 & 0.042 & 0.102 \\
\hline Rest Europe & 0.050 & 0.094 & 0.076 \\
\hline Asia & 0.335 & 0.317 & 0.327 \\
\hline Africa & 0.242 & 0.245 & 0.210 \\
\hline America & 0.129 & 0.087 & 0.108 \\
\hline Oceania & 0.035 & 0.036 & 0.027 \\
\hline Unemployment rate & 0.065 & 0.071 & 0.073 \\
\hline Young males rate & 0.199 & 0.215 & 0.208 \\
\hline Population & 233383 & 238585 & 266601 \\
\hline Total crime rate & 0.134 & 0.123 & 0.087 \\
\hline
\end{tabular}

Notes: Local Authority means weighted by population. Crime counts from Data.gov.uk with data provided by the 43 police force areas in England and Wales. Data from 2001 and 2011 Census is from the ONS. For the APS data we used the special licence dataset. Young Males Rate is males aged 15-39 over population and the unemployment rate is defined as those unemployed over the economically active population aged 16-64. The crime rates in the 2001 column use the crime counts of 2002, first year of the actual crime recording system.

Table 9 Changes in Crime and Immigration by Crime Types

Dependent variable: change in crime rate

Annual Population Survey, 2004/5-2010/11

\begin{tabular}{lll}
\hline Total crime & Violent crime & Property crime \\
IV & IV & IV \\
(1) & (2) & (3)
\end{tabular}

\section{A. England and Wales}

Change in immigrant share

Controls

Police force area fixed effects

Sample size

B. London

Change in immigrant share

Controls

Police force area fixed effects

Sample size

0.007 (0.078)
Yes
Yes
347

$0.120(0.088)$

Yes

Yes

33
$-0.010(0.021)$

$0.017(0.062)$

Yes

Yes

347

$0.011(0.019)$

Yes

Yes

33
Yes

Yes

347

$0.109(0.077)$

Yes

Yes

33

Notes: As for Table 4. Total crime is the sum of Property and Violent Crime. Property Crimes include burglary, theft and criminal damage, while Violent Crimes include violence against the person and robbery. Crime rates are obtained dividing the crime counts by total population from the APS. 
Table 10 Differential arrest rates by Nationality and offence type, London, 2009-2012

\begin{tabular}{|c|c|c|c|c|c|c|}
\hline & \multicolumn{6}{|c|}{$\begin{array}{l}\text { Dependent variable: monthly arrest rate per } 1,000 \text { population } \\
\text { (June-2009 / June-2012), London Boroughs }\end{array}$} \\
\hline & \multicolumn{3}{|c|}{ Violent offences } & \multicolumn{3}{|c|}{ Property offences } \\
\hline & $(1)$ & $(2)$ & $(3)$ & (4) & (5) & (6) \\
\hline Non-UK national & $0.270(0.099)$ & $-0.032(0.071)$ & $-0.091(0.057)$ & $0.277(0.099)$ & $0.095(0.075)$ & $0.055(0.050)$ \\
\hline Borough fixed effects & No & No & Yes & No & No & Yes \\
\hline Age band fixed effects & No & Yes & Yes & No & Yes & Yes \\
\hline Immigration offences & No & No & No & No & No & No \\
\hline Constant & $1.160(0.072)$ & $1.400(0.092)$ & $1.749(0.134)$ & $0.693(0.052)$ & $1.123(0.084)$ & $1.280(0.083)$ \\
\hline Sample size & 512 & 512 & 512 & 512 & 512 & 512 \\
\hline
\end{tabular}

Notes: As for Table 7. Property Offences include burglary, theft and criminal damage, while Violent Offences include violence against the person and robbery.

\section{Appendix B: Data Appendix}

\section{B1. Administrative units}

We construct 348 administrative units that are comparable over time, accounting for the administrative changes that took place in 2009. The main units of analysis are the Local Authorities (LAs) of England and Wales, over the decade 2001-2011.

\section{B2. Socio-demographic variables}

The sources with data at LA level for the period under study are: the Population Census (we use 1991, 2001 and 2011) and the Annual Population Survey (APS) for the interCensus years (we use yearly waves from April-2004/March-2005 to April-2010/March2011). LA disaggregation is available since 2004 in the special licence dataset of the APS. In the survey there is no data for the least populated LA (Isles of Scilly). We employ the remaining 347 comparable spatial units.

The base population is the 'usual resident population' which refers to people who live in the UK for 12 months or more, including those who have been resident for less than 12 months but intend to stay for a total period of 12 months or more. The usual resident population is the denominator for all the shares over population that we study.

The main immigration variable is country of birth, which is available in all the Census and the APS in the period that we study. However, the availability of data in terms of disaggregation by countries of origin varies within and across sources. We split the immigrant population in groups that could be tracked both for the Census and APS over time. We grouped the immigrants in the following countries/regions of origin: Ireland, European Union member countries as of 2001, A8 accession countries, Rest of Europe, India, Pakistan, Bangladesh, Sri Lanka, Rest of Asia, Kenya, South Africa, Ghana, Rest of Africa, Jamaica, North America, Rest of America and Oceania. The A8 countries who gained accession in May 2004 are: Czech Republic, Estonia, Hungary, Lithuania, Latvia, Poland, Slovakia and Slovenia. We include the A2 countries (Bulgaria and Romania) and Cyprus and Malta in the Rest of Europe category.

The immigrant share is defined as the immigrant population divided by the total population. Population growth refers to the growth of the total usual resident population. The unemployment rate is defined as the number of unemployed divided by the 
economically active population aged 16 to 64 years old. The young male population share is the ratio of the males aged 15-39 to the total population.

\section{B3. Crime variables}

The data on notifiable offences is from Data.gov.uk, supplied by the 43 police forces in England and Wales (we do not consider crimes recorded by other forces such as the British Transport Police). Total notifiable offences are available for every LA and are classified in the major type of offences: burglary, robbery, theft and handling stolen goods, violence against a person, sexual offences, drugs, fraud and forgery and other offences. We redefine total crime as the sum of violent crimes (violence against the person, sexual offences and robbery) and property crimes (burglary, theft and criminal damage).

Notifiable offences are consistently available since the fiscal year 2002/2003. Unfortunately we cannot use previous crime records due to changes in the recording system: in April 1998 the Home Office Counting Rules for recorded crime were expanded; and in April 2002 the National Crime Recording Standard (NCRS) was introduced across England and Wales.

In England and Wales crime is estimated to have increased by 10 percent (12 percent in the Metropolitan Police area) in the year of the introduction of NCRS. Violent crimes where the most affected, and burglaries the least affected category (see Simmons et al. 2003, and Jaitman and Machin 2013, for more details). To convert the crime counts into rates we divided the notifiable offences by the total usual resident population.

Through a Freedom of Information Act request we obtained a dataset on arrest counts for the 32 boroughs of the Metropolitan Police area. The records are monthly and start in April 2008. The data comes broken down by nationality (self-reported by the detainee), age, offence, month and borough. We are only able to use this data by nationality since June 2009 when the nationality field started to be mandatory. The dataset includes a list of 200 offences, which we grouped in the same categories as the recorded crime data. To convert the arrest counts into arrest rates, we divide the arrests by total population according to nationality status. We used the APS nationality variable as it is the self-reported by the respondent as it is in the case of the detainees.

\section{B4. Construction of instrumental variables}

To predict the change in the share of immigrants for the 2001-2011 period we use the Census immigrant count by country of birth of each of the 17 country/region groups previously defined, calculate their distribution across the 347 spatial units in 2001 and multiply each distribution by the 2001-2011 inflow of immigrants to the UK from the respective country. We divide the predicted inflow by the 2001 population. Then we add up the predicted inflow of the 17 groups to instrument the actual change in immigrant share per spatial unit.

To predict the change in the share of immigrants for the 2004/5-2010/11 period we use the APS and follow the same procedure, using as base distribution the average between 2004/5 and 2005/6 waves to increase precision. The A8 and Non-A8 IV is constructed in the same way, but only using the relevant groups for each case from the 17 categories. 
To predict the Change in Crime/Burglary Rate, 2002-2004 we use the Crime or Burglary Rate in 2002. We first scale the change in the Crime/Burglary Rate 20022004 to make it comparable to the 6 year period we analyse, multiplying it by three. Then, we use the Crime or Burglary Rate (in levels) in 2002 as the instrument.

\section{Competing interests}

The IZA Journal of Migration is committed to the IZA Guiding Principles of Research Integrity. The authors declare that they have observed these principles.

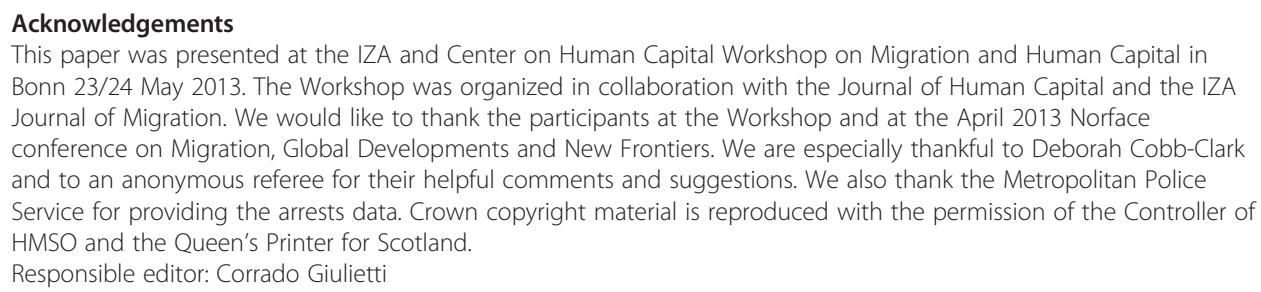

\section{Author details}

'Department of Economics, University College London, London, UK. ${ }^{2}$ Department of Economics, University College London and Centre for Economic Performance, London School of Economics, London, UK.

Received: 23 July 2013 Accepted: 19 September 2013

Published: 25 October 2013

\section{References}

Altonji J, Card D (1991) The effects of immigration on the labor market outcomes of less-skilled natives. In: Abowd J, Freeman R (ed) Immigration, trade and the labor market. University of Chicago Press, Chicago, pp 201-234

Barrett A, McCarthy Y (2008) Immigrants and welfare programmes: exploring the interactions between immigrant characteristics, immigrant welfare dependence and welfare policy. Oxford Review of Economic Policy 24:542-559

Bell B, Fasani F, Machin S (2013) Crime and immigration: evidence from large immigrant waves. Review of Economics and Statistics 95(4):1278-1290.

Bell B, Machin S (2013) Immigration and crime. In: Constant A, Zimmerman K (ed) International handbook on the economics of migration. Edward Elgar Publishing; Cheltenham, UK

Bianchi M, Buonanno P, Pinotti P (2012) Do immigrants cause crime? Journal of the European Economic Association 10:1318-1347

Borjas G (1999) The economic analysis of immigration, chapter 28. In: Ashenfelter O, Card D (ed) Handbook of labor economics, Vol. 3. , Amsterdam: North Holland, pp 1697-1760

Borjas G, Hilton L (1996) Immigration and the welfare state: immigrant participation in means-tested entitlement programs. Quarterly Journal of Economics 111:575-604

Card D (2001) Immigrant inflows, native outflows, and the local market impacts of higher immigration. Journal of Labor Economics 19:22-64

Card D (2005) Is the new immigration really so bad? Economic Journal 115:F300-F323

Card D (2009) Immigration and inequality. American Economic Review 99:1-21

Dustmann C, Frattini T, Preston I (2013) The effect of immigration along the distribution of wages. Rev Econ Stud 80:145-173

Jaitman L, Machin S (2013) Crime and immigration: new evidence from England and Wales, discussion paper 1238. Centre for Economic Performance, London School of Economics; London, UK

Office for National Statistics (ONS) Annual population survey (2004-2012). , Colchester, Essex. UK Data Archive, SN5257, SN5503, SN5737, SN6040, SN6311, SN6588, SN6897, SN7173

Office for National Statistics (ONS) 2001 and 2011 census: aggregate data (England and Wales). UK Data Service Census Support. Downloaded from: http://infuse.mimas.ac.uk

Office of Population Censuses and Surveys 1991 Census: aggregate data (England and Wales). UK Data Service Census Support. Downloaded from: http://casweb.mimas.ac.uk

Sa F (2011) Immigration and house prices in the UK. IZA Discussion Paper 5893

Saiz A (2007) Immigration and housing rents in American cities. Journal of Urban Economics 61:345-371

Simmons J, Legg C, Hosking R (2003) National crime recording standard (NCRS): an analysis of the impact on recorded crime. Companion volume to crime in England and Wales 2002/2003. Home office online reports 31/03 and 32/03. Home Office, London

Spenkuch J (2011) Understanding the impact of immigration on crime, MPRA paper No. 31171. University Library of Munich, Munich

Wadsworth J (2013) Mustn't grumble. Immigration, health and health service use in the UK and Germany, Fiscal Studies 34:55-82

doi:10.1186/2193-9039-2-19

Cite this article as: Jaitman and Machin: Crime and immigration: new evidence from England and Wales. IZA Journal of Migration 2013 2:19. 